\title{
Association of Circulating Fasting TNF- A with Hyperglycemia is Stronger than with Body Mass Index in Newly Diagnosed Bangladeshi Type 2 Diabetic Subjects
}

\author{
Shahangir Biswas ${ }^{1}$, Syed M Kamaluddin², Muhammad Saiedullah², Motiar Rahman ${ }^{3}$, Amirul Islam $^{3}$, Omar Faruque $^{1 *}$ and Liaquat Ali ${ }^{4}$ \\ ${ }^{1}$ Department of Physiology and Molecular Biology, Bangladesh University of Health Sciences, Dhaka, Bangladesh \\ ${ }^{2}$ Department of Applied Laboratory Sciences, Bangladesh University of Health Sciences, Dhaka, Bangladesh \\ ${ }^{3}$ Department Biochemistry \& Molecular Biology, Rajshahi Univesity, Rajshahi, Bangladesh \\ ${ }^{4}$ Department of Biochemistry \& Cell Biology, Bangladesh University of Health Sciences, Dhaka, Bangladesh
}

\begin{abstract}
Background and aim: Insulin resistance and hypo-insulinemia are the major problems in Type 2 Diabetes Mellitus (T2DM). Epidemiological evidences suggest that obesity is linked with insulin resistance. Inflammatory cytokines such as TNF- $\alpha$ has also been associated with obesity and insulin resistance. The present study aims to evaluate fasting serum TNF- $\alpha$ in newly diagnosed type 2 diabetic subjects in different BMI group to observe its association with insulin sensitivity and obesity.

Methods: A total number of 145 newly diagnosed T2DM subjects were recruited in this study. On a prescheduled morning fasting and postprandial ( $2 \mathrm{hrs}$ after $75 \mathrm{~g}$ glucose load) blood was drawn. Serum glucose was measured by glucose-oxidase method, lipid profile by enzymatic end-point method, insulin and TNF- $\alpha$ by ELISA methods. Insulin secretory capacity $(\mathrm{HOMA} \% \mathrm{~B})$ and insulin sensitivity $(\mathrm{HOMA} \% \mathrm{~S})$ were calculated using fasting glucose and insulin by HOMA-CIGMA software. SPSS for Windows was used for statistical analysis.

Results and conclusion: The subjects were divided into three groups on the basis of BMI cut-off points suggested by WHO for the Asian population (Gr1: BMI $\leq 23$, Gr2: BMI 23.1-27.5, Gr3: BMI>27.5). The fasting serum insulin and TNF- $\alpha$ levels were significantly $(p<0.005)$ higher in group 3 than the other groups. HOMA\%B was significantly higher in $\mathrm{Gr} 3$ and $\mathrm{HOMA} \% \mathrm{~S}$ was significantly lower in group 3 compared to group 1 and group 2. From multiple linear regression analysis it can be concluded that both BMl and postprandial serum glucose had potential effects on serum TNF- $\alpha$ level but the later one had stronger.
\end{abstract}

Keywords: TNF- $\propto$; Body mass index; Type 2 diabetes

\section{Introduction}

Reduced insulin-mediated glucose disposal is a dominant metabolic feature of obesity and type 2 diabetes mellitus and the basis of the abnormalities in carbohydrate, fat, and protein metabolism in diabetes is deficient action of insulin on target tissues [1,2]. This phenomenon is due to peripheral cells being either completely or partially resistant to the effects of insulin [3]. Many clinicians point to certain habits, such as sedentary lifestyle and high calorie and fat intake, as the main culprit of diabetes [4]. Interventions focusing on weight loss, diet modifications, and regular physical exercise of at least 150 minutes per week reduce the incidence of diabetes in at-risk patients. These activities also reduce hemoglobin $A_{1 C}$ levels in type 2 diabetes [5]. Genetic links have likewise been recognized. Researchers discovered at least 36 genes associated with diabetes [6]. A high concordance level among identical twins shows that type 2 diabetes is heritable [7]. It is uncertain at this point whether inflammation occurs prior to or after the onset of diabetes. Specific cytokines such as TNF- $\alpha$, IL-6, and C-Reactive Protein (CRP) are elevated in type 2 diabetic patients in comparison to non-diabetic controls [8]. The role of inflammation in diabetes is still under investigation, it is important to consider which pathways may be targeted therapeutically. For example, TNF- $\alpha$ induces pathways that lead to increased insulin resistance throughout the body [9]. Tumor necrosis factor- $\alpha$ is the pre-inflammatory cytokine secreted by several types of cells such as macrophages, monocytes, nutrophils and T-cells. TNF- $\alpha$ is directly implicated in the destruction of $\beta$-cells from in vitro studies on isolated islets and profound inflammatory effects in vivo by acting directly on T lymphocytes [10,11]. Type 2 diabetes, particularly when poorly controlled, involves disease of the innate immune system and manifest as chronic low-grade inflammation [12]. Consistent with this hypothesis, high levels of circulating acute phase proteins in particular IL-6, tumor necrosis factor $\alpha$ (TNF- $\alpha$ ), other mediators of inflammation such as serum-amyloid A (S-AA) and hs- CRP and their association with obesity and insulin resistance have been previously documented [13-17]. Additionally several studies have demonstrated elevated levels of IL6 and TNF- $\alpha$ among individuals with insulin resistance and diabetes. It has been examined the effects of TNF- $\alpha$ on proximal steps in the insulin-signaling pathway [18]. An important factor that could potentially contribute to inflammation is chronic hyperglycemia [19]. Inadequate glucose control and its associated inflammation in diabetes have been implicated in the pathogenesis of atherosclerosis, impaired lung function and cardiovascular disease [20]. Since TNF- $\alpha$ is associated with both insulin sensitivity and obesity therefore, this study was designed to explore the serum level of TNF- $\alpha$

*Corresponding author: Omar Faruque, Associate Professor, Bangladesh University of Health Sciences, Physiology \& Molecular Biology, 125/1 Darus Salam, Mirpur-1, Dhaka, Bangladesh, Tel: 880 1797091813; E-mail: faruqueomar@yahoo.com

Received May 05, 2014; Accepted September 10, 2014; Published September 18, 2014

Citation: Biswas S, Kamaluddin SM, Saiedullah M, Rahman M, Islam A, et al (2014) Association of Circulating Fasting TNF-A with Hyperglycemia is Stronger than with Body Mass Index in Newly Diagnosed Bangladeshi Type 2 Diabetic Subjects. J Diabetes Metab 5: 429 doi:10.4172/2155-6156.1000429

Copyright: $\odot 2014$ Biswas S, et al. This is an open-access article distributed under the terms of the Creative Commons Attribution License, which permits unrestricted use, distribution, and reproduction in any medium, provided the original author and source are credited. 
Citation: Biswas S, Kamaluddin SM, Saiedullah M, Rahman M, Islam A, et al. (2014) Association of Circulating Fasting TNF-A with Hyperglycemia is Stronger than with Body Mass Index in Newly Diagnosed Bangladeshi Type 2 Diabetic Subjects. J Diabetes Metab 5: 429 doi:10.4172/21556156.1000429

Page 2 of 5

in relation to insulin sensitivity and with the different degrees of BMI (Body Mass Index) of the study subjects.

\section{Materials and Methods}

In this cross-sectional-observational study 145 newly diagnosed type 2 diabetic subjects were recruited purposively from the OutPatient-Department (OPD) of Bangladesh Institute of Health Sciences, Dhaka, Bangladesh. Subjects were considered as T2DM using WHO guidelines [21]. On a prescheduled morning, subjects were requested to come after overnight fast (eight to ten hours) for fasting blood sample. Informed written consent was taken and subjects were then given $75 \mathrm{~g}$ glucose dissolved in $250 \mathrm{ml}$ water. Blood was taken by venepuncture in fasting condition and two hours after glucose load. After 10-15 minutes of collection blood samples were centrifuged for 10-15 minutes at $3000 \mathrm{rpm}$ to obtain serum and were kept frozen at $-30^{\circ} \mathrm{C}$ until analysis.

Anthropometric and clinical parameters were also recorded using a predesigned questionnaire by standard techniques. Serum glucose was measured by Glucose-oxidase (GOD-PAP) method, serum lipid profile and creatinine by enzymatic colorimetric method and serum SGPT by UV method using ALT (GPT) opt.kit (Randox Laboratories Ltd, UK). Serum insulin and TNF- $\alpha$ by Enzyme Linked Immunosorbent Assay (ELISA) method (Linco Research Inc, and Assaypro, USA respectively).

Insulin secretory capacity (HOMA\%B) and insulin sensitivity (HOMA\%S) were estimated using fasting glucose and fasting insulin levels by HOMA - CIGMA software [22].

\begin{tabular}{|c|c|}
\hline Parameters & Mean \pm SD \\
\hline Age (yrs) & $45 \pm 10$ \\
\hline BMI $\left(\mathbf{k g} / \mathbf{m}^{2}\right)$ & $25.7 \pm 4.3$ \\
\hline WHR & $0.97 \pm 0.02$ \\
\hline SBP (mm-Hg) & $121 \pm 15$ \\
\hline DBP (mm-Hg) & $79 \pm 9$ \\
\hline FSG (mmol/L) & $10.5 \pm 4.6$ \\
\hline PPSG (mmol/L) & $18.2 \pm 5.5$ \\
\hline Insulin $(\mu \mathrm{IU} / \mathrm{ml})$ & $12.2 \pm 7.2$ \\
\hline Triglyceride (TG, mg/dl) & $230 \pm 139$ \\
\hline Total Cholesterol (mg/dl) & $172 \pm 41$ \\
\hline HDL-Cholesterol (mg/dl) & $36 \pm 10$ \\
\hline LDL-Cholesterol (mg/dl) & $94 \pm 36$ \\
\hline HOMA \%B & $56 \pm 43$ \\
\hline HOMA \%S & $67 \pm 74$ \\
\hline TNF- $\alpha(\mathrm{pg} / \mathrm{ml})$ & $24.16 \pm 12.02$ \\
\hline
\end{tabular}

Results are expressed as mean \pm SD, BMI: Body Mass Index; WHR: WaistHip ratio; SBP: Systolic Blood Pressure; DBP: Diastolic Blood Pressure; FSG: Fasting Serum Glucose; PPSG: Postprandial Serum Glucose; HDL: High-Density Lipoprotein; LDL: Low-Density Lipoprotein; HOMA\%B, Insulin Secretory Capacity; HOMA\%S, Insulin Sensitivity, TNF-a: Tumor necrosis factor- $\alpha$.

Table 1: Clinical and biochemical characteristics of the study subjects $(n=145)$.

\section{Statistical analysis}

Statistical analysis was performed using SPSS (Statistical Package for Social Science) version 11.5 for Windows (SPSS Inc., Chicago, Illinois, USA). All data were expressed as mean \pm SD (standard deviation) and/or percentage (\%) as appropriate. The statistical significance of differences between the values was assessed by independent student's $t$ test (as appropriate). Correlation was also observed among the parameters using Pearson's correlation and multiple linear regression analysis. A two-tailed $\mathrm{p}$ value of $<0.05$ was considered statistically significant.

\section{Results}

\section{Clinical and biochemical characteristics of the study subjects (Table 1)}

Age (Mean $\pm \mathrm{SD}$ ) of the study subjects was $45 \pm 10$ years. BMI, Waist to hip ratio (WHR), Systolic Blood Pressure (SBP) and Diastolic Blood Pressure (DBP) were presented in Table 1.

Fasting and postprandial (after 75g glucose load) blood glucose $(\mathrm{mmol} / \mathrm{l})$ of the study subjects were $10.5 \pm 4.6$ and $18.2 \pm 5.6$. Mean \pm SD serum insulin $(\mu \mathrm{IU} / \mathrm{ml})$ level of the study subjects was $12.2 \pm 7.2$. Mean triglyceride $(\mathrm{mg} / \mathrm{dl})$ level of the study subjects was higher than the reference range, cholesterol, HDL and LDL levels were within normal range. Insulin secretory capacity $(\mathrm{HOMA} \% \mathrm{~B})$ and insulin sensitivity (HOMA\%S) were calculated using fasting glucose and fasting insulin values using HOMA-CIGMA software and the values were $56 \pm 43$ and $67 \pm 74$ respectively. Mean \pm SD serum TNF- $\alpha(\mathrm{pg} / \mathrm{ml})$ level among the study subjects was $24.16 \pm 12.02$ (Table 1 ).

The study subjects were categorized according to BMI cut-offpoints suggested by WHO for Asian population $(\mathrm{Gr} 1$ : $\mathrm{BMI} \leq 23, \mathrm{Gr} 2$ : BMI 23.1-27.5, Gr3: BMI>27.5), fasting serum insulin levels in $\mathrm{Gr}$ 3 has been found to be significantly higher compared to Gr 1 and Gr 2. Similarly serum TNF-a level was significantly higher in Gr 3 compared to Gr 1 and Gr 2 (Table 2). Accordingly HOMA B was significantly increased in Gr3 compared to Gr2, on the other hand HOMA $\%$ S was significantly decreased in Gr 3 compared to Gr 1 and Gr 2 (Table 2).

Fasting serum TNF- $\alpha$ concentrations were reanalyzed on the basis of fasting and postprandial glucose concentrations and it has been found that TNF- $\alpha$ was significantly $(\mathrm{p}<0.05)$ increased when fasting glucose was more than $16 \mathrm{mmol} / \mathrm{l}$ and postprandial glucose was more that $24 \mathrm{mmol} / \mathrm{l}$ (Table 3 ).

In regression analysis (Figure 1) it has been found that TNF- $\alpha$ was positively associated with BMI and postprandial serum glucose and negatively associated with insulin sensitivity. In multiple linear regression analysis, positive association of TNF- $\alpha$ with BMI $(\beta=0.252$, $\mathrm{p}=0.003)$ and postprandial glucose $(\beta=0.615, \mathrm{p}=0.001)$ still preserved when the effects of age and blood pressure were adjusted (Table 4 ).

\begin{tabular}{|l|c|c|c|c|c|}
\hline & Gr1 & Gr2 & t/p values & \multicolumn{2}{|c|}{ Gr3 } \\
Parameters & $\mathbf{n = 4 8}$ & $\mathbf{n = 7 0}$ & Gr1 vs. Gr3 & Gr1 vs. Gr2 & $-4.82 / 0.0001$ \\
\hline Insulin $(\boldsymbol{\mu l U} / \mathbf{m l})$ & $9.8 \pm 5.5$ & $11.4 \pm 6.6$ & $16.6 \pm 7.6$ & $-1.29 / 0.199$ & $-3.75 / 0.001$ \\
\hline TNF- $\alpha(\mathbf{n g} / \mathbf{m l})$ & $20.1 \pm 10.9$ & $22.2 \pm 10.7$ & $29.1 \pm 12.9$ & $-1.006 / 0.317$ & $-3.58 / 0.001$ \\
\hline HOMA\% B & $52 \pm 40$ & $50 \pm 36$ & $70 \pm 53$ & $0.205 / 0.791$ & $-1.7 / 0.08$ \\
\hline HOMA\% S & $86 \pm 105$ & $69 \pm 62$ & $39 \pm 18$ & $1.03 / 0.303$ & $2.87 / 0.006$ \\
\hline
\end{tabular}

$\mathrm{Gr} 1, \mathrm{BMI} \leq 23 \mathrm{Kg} / \mathrm{m}^{2} ; \mathrm{Gr}$, BMI 23.1-27.5; Gr3, BMI>27.5

Table 2: Biochemical characteristics of the study subjects according to BMI. 
Citation: Biswas S, Kamaluddin SM, Saiedullah M, Rahman M, Islam A, et al. (2014) Association of Circulating Fasting TNF-A with Hyperglycemia is Stronger than with Body Mass Index in Newly Diagnosed Bangladeshi Type 2 Diabetic Subjects. J Diabetes Metab 5: 429 doi:10.4172/21556156.1000429

Page 3 of 5

\begin{tabular}{|c|c|c|c|}
\hline Groups & & Serum TNF- $\alpha$ & t/p Values \\
\hline \multirow{3}{*}{ Fasting Glucose Category } & Gr1, Upto 8mmol/l $(n=53)$ & $24.4 \pm 12.7$ & \multirow{3}{*}{$\begin{array}{l}\text { Gr1 vs Gr2 : } 1.455 / 0.148 \\
\text { Gr1 vs Gr3 : }-2.039 / 0.045 \\
\text { Gr2 vs Gr3 : }-2.382 / 0.028\end{array}$} \\
\hline & $\mathrm{Gr} 2,8.01-16 \mathrm{mmol} / \mathrm{l}(\mathrm{n}=73)$ & $21.7 \pm 7.8$ & \\
\hline & Gr $3,>16 \mathrm{mmol} / \mathrm{l}(\mathrm{n}=19)$ & $32.4 \pm 18.7$ & \\
\hline \multirow{3}{*}{ Postprandial Glucose Category } & Gr1, Upto $16 \mathrm{mmol} / \mathrm{l}(\mathrm{n}=65)$ & $23.1 \pm 11.6$ & \multirow{3}{*}{$\begin{array}{l}\text { Gr1 vs Gr2 :-0.089/0.93; } \\
\text { Gr1 vs Gr3 : }-2.08 / 0.041 \\
\text { Gr2 vs Gr3 : }-2.23 / 0.028\end{array}$} \\
\hline & Gr2, $16.01-24 \mathrm{mmol} / \mathrm{l}(\mathrm{n}=59)$ & $23.2 \pm 9.1$ & \\
\hline & $\mathrm{Gr} 3,>24 \mathrm{mmol} / \mathrm{l}(\mathrm{n}=21)$ & $30.1 \pm 17.9$ & \\
\hline
\end{tabular}

Table 3: Serum TNF- $\alpha$ concentrations according to fasting and postprandial glucose concentrations.

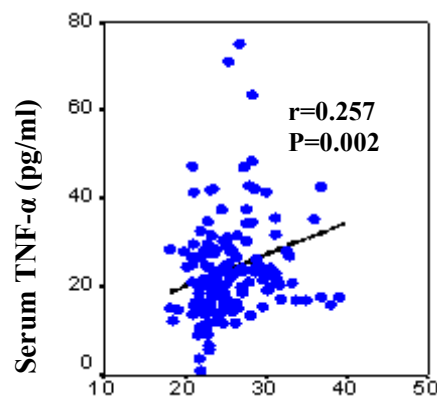

Body Mass Index (BMI, $\left.\mathrm{kg} / \mathrm{m}^{2}\right)$

A

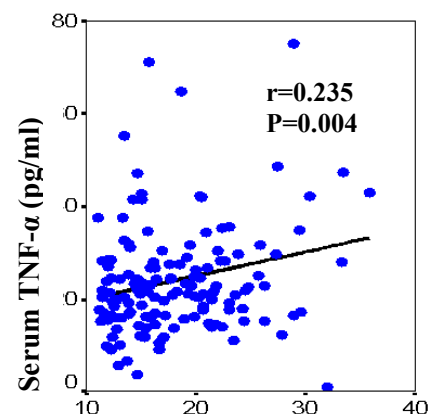

Postprandial Serum Glucose (mmol/l)

B

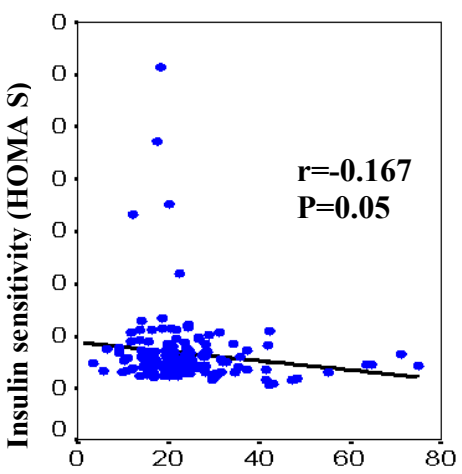

Fasting serum TNF- $\alpha(\mathrm{pg} / \mathrm{ml})$

C

Figure 1: Association of serum TNF- $\alpha$ with Body Mass Index (A), postprandial serum glucose (B) and insulin sensitivity (C).

\begin{tabular}{|c|c|c|c|c|c|}
\hline \multicolumn{3}{|l|}{ Model 1} & \multicolumn{3}{|c|}{ Model 2} \\
\hline Variables & $\beta$ & $\mathbf{p}$ & Variables & $\beta$ & $p$ \\
\hline Age & 0.116 & 0.146 & Age & 0.191 & 0.023 \\
\hline BMI & 0.252 & 0.003 & BMI & 0.243 & 0.006 \\
\hline SBP & 0.125 & 0.377 & SBP & 0.033 & 0.823 \\
\hline DBP & 0.022 & 0.872 & DBP & 0.0001 & 0.999 \\
\hline Fasting Glucose & -0.338 & 0.070 & HOMA B & -0.112 & 0.212 \\
\hline PPSG & 0.615 & 0.001 & HOMA S & -0.114 & 0.200 \\
\hline Fasting Insulin & 0.116 & 0.189 & & & \\
\hline
\end{tabular}

SBP: Systolic Blood Pressure; DBP: Diastolic Blood Pressure; PPSG: Post-Prandial Serum Glucose

Table 4: Relationship of serum TNF-a with BMI, postprandial glucose and insulin sensitivity (HOMA S) adjusted with other variables using multiple linear regression analysis.

\section{Discussion}

Type 2 Diabetes mellitus has been suggested as a disease of the innate immune system; responsible for an ongoing cytokine mediated acute phase response and low grade chronic inflammation which may be involved in the atherosclerosis of diabetes mellitus [23]. Insulin resistance is a common feature of type 2 diabetes mellitus, and inflammatory cytokines such as TNF- $\alpha$ and IL- 6 have been linked to insulin resistance [24]. The underlying mechanisms of the development of insulin resistance are not clear, but a key mechanism 
Citation: Biswas S, Kamaluddin SM, Saiedullah M, Rahman M, Islam A, et al. (2014) Association of Circulating Fasting TNF-A with Hyperglycemia is Stronger than with Body Mass Index in Newly Diagnosed Bangladeshi Type 2 Diabetic Subjects. J Diabetes Metab 5: 429 doi:10.4172/21556156.1000429

Page 4 of 5

by which TNF- $\alpha$ was thought to induce insulin resistance involved serine phosphorylation of the Insulin Receptor Substrate-1 (IRS1) [19]. TNF- $a$ level has been shown to be increased in patients with type 2 diabetes mellitus. However, whether it is involved in the development of type 2 diabetes mellitus or vice versa is not clear. It has been reported that inflammation contributes to insulin resistance in obese and diabetic patients [25]. Inflammatory molecules such as TNF- $\alpha$ and IL- 6 may therefore play an important role. It was found that diabetic patients had elevated levels of TNF- $\alpha$, which reinforces this hypothesis. Epidemiological evidence suggests that inflammatory markers like TNF- $\alpha$ and IL- 6 predict the development of diabetes and glucose disorders $[26,27]$. TNF- $\alpha$ contributes to the pathogenesis of insulin resistance, type 2 diabetes, and abnormal adiposity or lipid disorders [28]. Some authors have found increased serum TNF- $\alpha$ and IL- 6 concentration in type 2 diabetic $[29,30]$ and IGT subjects but Choi et al. [31] did not found any association of TNF- $\alpha$ and IL- 6 with IGT development. TNF- $\alpha$ have not been extensively studied in diabetic subjects with different BMI group and in different glycemic status levels.

Studied diabetic subjects were categorized according to BMI (Gr1: $\mathrm{BMI} \leq 23$, Gr2: $\mathrm{BMI}$ 23.1-27.5, Gr3: $\mathrm{BMI}>27.5$ ), Gr 3 was found to have significantly $(\mathrm{p}=0.001)$ higher levels of insulin compared to $\mathrm{Gr} 1$ and $\mathrm{Gr}$ 2 . When insulin secretory capacity (HOMA\%B) and insulin sensitivity (HOMA\%S) were analyzed according to $\mathrm{BMI}$, it has been found that HOMA\%B was significantly increased in subjects with BMI $>27.5 \mathrm{~kg} /$ $\mathrm{m}^{2}(\mathrm{Gr} 3)$ compared to $\mathrm{Gr}$, on contrary HOMA\%S was significantly decreased in Gr 3 compared to Gr 1 and Gr 2. Therefore BMI 27.5 is a worsening status of overweight where $\beta$-cells of the pancreas secrete higher amounts of insulin with less functionality.

In a previous study on Bangladeshi populations the serum TNF- $\alpha$ has been found to be significantly higher in Type 2 DM subjects compared to Control, which supported by another study in India where they found that higher TNF-a level was associated in IGT and Type 2 DM subjects. Studies done in abroad had documented that serum TNF- $\alpha$ concentrations were higher in IGT than in NGT (Normal Glucose Tolerance) while a Korean study found no elevation in serum TNF- $\alpha$ concentrations in prediabetic patients compared to Control In the present study serum TNF- $\alpha$ was measured in Type 2 DM subjects with different BMI groups and found that serum TNF- $\alpha$ was increased with the increase of BMI. In this study both the Gr2 and Gr3 have shown significantly $(p<0.05)$ higher levels of serum TNF- $\alpha$ compared to Gr1. Therefore, BMI might be an important indicator for the increase of serum TNF- $\alpha$ in Bangladeshi type 2 diabetic subjects. When serum TNF- $\alpha$ values were determined according to glycemic status, it was found that TNF- $\alpha$ was increased with increase of both fasting and postprandial serum glucose levels. Serum TNF- $\alpha$ was found to be increased significantly $(\mathrm{p}<0.05)$ when fasting glucose was more than $16 \mathrm{mmol} / \mathrm{l}$ and postprandial serum glucose was more than $24 \mathrm{mmol} / 1$. Increased serum TNF- $\alpha$ may decreases insulin sensitivity which may play roles in the development of extreme hyperglycemia or vice versa. Therefore both the fasting and postprandial serum glucose at certain levels might have potential association with serum TNF- $\alpha$.

We have looked the determinants of TNF- $\alpha$ elevation in diabetic subjects using bivariate correlation analysis and it has been found that BMI, waist circumference, hip circumference and postprandial serum glucose is positively $(r=0.257, p=0.002 ; r=0.201, p=0.016$ and $r=0.179$, $\mathrm{p}=0.031$ respectively) associated with fasting serum TNF-alpha in type 2 diabetic subjects. On the other hand serum HDL concentrations and insulin sensitivity showed significantly negative association $(\mathrm{r}=-0.184$, $\mathrm{p}=0.027 ; \mathrm{r}=-0.167, \mathrm{p}=0.050$ respectively) with TNF- $\alpha$. On multiple linear regression analysis, when other cofactors like age, systolic blood pressure, diastolic blood pressure, fasting glucose and fasting insulin values were adjusted, both BMI $(\mathrm{p}=0.003)$ and postprandial serum glucose ( $\mathrm{p}=0.001)$ was found to be significantly associated with serum TNF- $\alpha$ and the association of the latter one was found stronger [3234]. Type 2 diabetes also has become the leading cause of end-stage renal disease in the world, and the number of patients diagnosed each year with end-stage renal disease attributed to type 2 diabetes is rising [35]. There is now evidence that activated innate immunity and inflammation are relevant factors in the pathogenesis of diabetes. Furthermore, different inflammatory molecules, including proinflammatory cytokines such as tumor necrosis factor-alpha (TNFalpha), play a critical role in the development of diabetic microvascular complications, including nephropathy [36,37]. A previous study showed that development of diabetic nephropathy is commonly thought to result from the cumulative interactions among multiple metabolic and hemodynamic factors which activate common intracellular signaling pathways that in turn trigger the production of cytokines and growth factors, leading to renal disease [38]. Another study showed that the prevalence of nephropathy significantly increased with increased BMI [39]. Therefore the viewpoints of the above discussion could be concluded as: a) increased BMI influences on insulin levels, insulin sensitivity and fasting serum TNF- $\alpha$. b) after certain levels, both fasting and postprandial serum glucose levels significantly effects on the circulating concentration of TNF- $\alpha, c)$ fasting serum TNF- $\alpha$ shows positive association with $\mathrm{BMI}$ and postprandial serum glucose but the later one is more potential

\section{References}

1. DeFronzo RA, Ferrannini E (1991) Insulin resistance: a multifaceted syndrome responsible for NIDDM, obesity, hypertension, dyslipidemia, and atherosclerotic cardiovascular disease. Diabetes Care 14: 173-194.

2. Lucke-Wold BP, Turner RC, Lucke-Wold AN, Rosen CL, Huber JD (2012) Age and the metabolic syndrome as risk factors for ischemic stroke: improving preclinical models of ischemic stroke. Yale J Biol Med 85: 523-539.

3. American Diabetes Association (2010) Diagnosis and Classification of Diabetes Mellitus. Diabetes Care 33: S62-S69.

4. Mahler RJ, Adler ML (1999) Clinical review 102: Type 2 diabetes mellitus: update on diagnosis, pathophysiology, and treatment. J Clin Endocrinol Metab 84: $1165-1171$.

5. Berg GD, Wadhwa S (2002) Diabetes disease management in a communitybased setting. Manag Care 11: 42, 45-50.

6. Ripsin CM, Kang H, Urban RJ (2009) Management of blood glucose in type 2 diabetes mellitus. Am Fam Physician 79: 29-36.

7. Herder C, Roden M (2011) Genetics of type 2 diabetes: pathophysiologic and clinical relevance. Eur J Clin Invest 41: 679-692.

8. Medici F1, Hawa M, lanari A, Pyke DA, Leslie RD (1999) Concordance rate for type II diabetes mellitus in monozygotic twins: actuarial analysis. Diabetologia 42: $146-150$

9. Pickup JC (2004) Inflammation and activated innate immunity in the pathogenesis of type 2 diabetes. Diabetes Care 27: 813-823.

10. Hotamisligil GS, Arner P, Caro JF, Atkinson RL, Spiegelman BM (1995) Increased adipose tissue expression of tumor necrosis factor-alpha in human obesity and insulin resistance. J Clin Invest 95: 2409-2415.

11. Thomas HE, Darwiche R, Corbett JA, Kay TW (1999) Evidence that beta cell death in the nonobese diabetic mouse is Fas independent. J Immunol 163: 1562-1569.

12. Grewal IS, KD Grewal, S Wong, DE Picarella, CA Janeway,et al. (1963) Local expression of transgene encoded TNF-a in islet prevents autoimmune diabetes in nonobese diabetic (NOD) mice by preventing the development of autoreactive islet-specific T cells. J Exp Med 184: 1963.

13. Dennis RJ, Maldonado D, Rojas MX, Aschner P, Rondón M, et al. (2010) 
Citation: Biswas S, Kamaluddin SM, Saiedullah M, Rahman M, Islam A, et al. (2014) Association of Circulating Fasting TNF-A with Hyperglycemia is Stronger than with Body Mass Index in Newly Diagnosed Bangladeshi Type 2 Diabetic Subjects. J Diabetes Metab 5: 429 doi:10.4172/21556156.1000429

Inadequate glucose control in type 2 diabetes is associated with impaired lung function and systemic inflammation: a cross-sectional study. BMC Pulm Med 10: 38 .

14. Pickup JC, Chusney GD, Thomas SM, Burt D (2000) Plasma interleukin-6, tumour necrosis factor alpha and blood cytokine production in type 2 diabetes. Life Sci 67: 291-300

15. Rytter E, Vessby B, Asgård R, Johansson C, Sjödin A, et al. (2009) Glycaemic status in relation to oxidative stress and inflammation in well-controlled type 2 diabetes subjects. Br J Nutr 101: 1423-1426.

16. Yang RZ, Lee MJ, Hu H, Pollin TI, Ryan AS, et al. (2006) Acute-phase serum amyloid $A$ : an inflammatory adipokine and potential link between obesity and its metabolic complications. PLoS Med 3: e287.

17. Pradhan AD, Manson JE, Rifai N, Buring JE, Ridker PM (2001) C-reactive protein, interleukin 6 , and risk of developing type 2 diabetes mellitus. JAMA 286: 327-334.

18. Hu FB, Meigs JB, Li TY, Rifai N, Manson JE (2004) Inflammatory markers and risk of developing type 2 diabetes in women. Diabetes 53: 693-700.

19. Hotamisligil GS, Peraldi P, Budavari A, Ellis R, White MF, et al. (1996) IRS-1mediated inhibition of insulin receptor tyrosine kinase activity in TNF-alpha- and obesity-induced insulin resistance. Science 271: 665-668.

20. Alexandraki K, Piperi C, Kalofoutis C, Singh J, Alaveras A, et al. (2006) Inflammatory process in type 2 diabetes: The role of cytokines. Ann N Y Acad Sci 1084: 89-117.

21. World health organization consultation (1999) Definition, Diagnosis and classification of Diabetes mellitus and its complications, part 1: Diagnosis and classification of Diabetes mellitus, Report of WHO consultation. Geneva: World Health Organization.

22. Levy JC, Matthews DR, Hermans MP (1998) Correct homeostasis mode assessment (HOMA) evaluation uses the computer program. Diabetes Care 21: 2191-2192.

23. Gerich JE, Smith TM (2003) ß-cell defects and pancreatic abnormalities in type 2 diabetes. In: Textbook of Diabetes, third edition. John C. Pickup \& Gareth Williams, Eds, Blachvell Sciencepp: 23.1 - 23.11.

24. Fernández-Real JM, Ricart W (2003) Insulin resistance and chronic cardiovascular inflammatory syndrome. Endocr Rev 24: 278-301.

25. Hotamisligil GS (2003) Inflammatory pathways and insulin action. Int J Obes Relat Metab Disord 27 Suppl 3: S53-55.

26. Sun Y, Liu S, Ferguson S, Wang L, Klepcyk P, et al. (2002) Phosphoenolpyruvate carboxykinase overexpression selectively attenuates insulin signaling and hepatic insulin sensitivity in transgenic mice. J Biol Chem 277: 23301-23307.
27. Roden M, Petersen KF, Shulman GI (2001) Nuclear magnetic resonance studies of hepatic glucose metabolism in humans. Recent Prog Horm Res 56: 219-237.

28. Schmidt MI, Duncan BB, Sharrett AR, Lindberg G, Savage PJ, et al. (1999) Markers of inflammation and prediction of diabetes mellitus in adults (Atherosclerosis Risk in Communities study): a cohort study. Lancet 353: 16491652.

29. Moller DE (2000) Potential role of TNF-alpha in the pathogenesis of insulin resistance and type 2 diabetes. Trends Endocrinol Metab 11: 212-217.

30. Cardellini M, Andreozzi F, Laratta E, Marini MA, Lauro R, et al. (2007) Plasma IL-6 levels are increased in subjects with Impaired glucose tolerance but not in those with impaired fasting glucose in a cohort of Italian Caucasians. Diabetes Metab Res 23: 141-145.

31. Choi KM, Lee J, Lee KW, Seo JA, Oh JH, et al. (2004) Comparison of serum concentrations of C-reactive protein, TNF-alpha and IL-6 between elderly Korean women with normal and Impaired Glucose Tolerance. Diabetes Research and Clinical practice 64: 99-106.

32. Hossain M, Faruque MO, Kabir G, Khan I, Sikdar D, et al. (2012) Association of serum tumour necrosis factor-a and interleukin- 6 with insulin secretion and insulin resistance in subjects with type 2 diabetes in a Bangladeshi population. S Afr J Diab Vasc Dis 9: 29-30.

33. Swaroop JJ, Rajarajeswari D, Naidu JN (2012) Association of TNF-ît with insulin resistance in type 2 diabetes mellitus. Indian J Med Res 135: 127-130.

34. Miyazaki Y, Pipek R, Mandarino LJ, DeFronzo RA (2003) Tumor necrosis factor alpha and insulin resistance in obese type 2 diabetic patients. Int J Obes Relat Metab Disord 27: 88-94.

35. Müller S, Martin S, Koenig W, Hanifi-Moghaddam P, Rathmann W, et al. (2002) Impaired glucose tolerance is associated with increased serum concentrations of interleukin 6 and co-regulated acute-phase proteins but not TNF-alpha or its receptors. Diabetologia 45: 805-812.

36. Eggers PW (2011) Has the incidence of end-stage renal disease in the USA and other countries stabilized? Curr Opin Nephrol Hypertens 20: 241-245.

37. Navarro JF, Mora-Fernández C (2006) The role of TNF-alpha in diabetic nephropathy: pathogenic and therapeutic implications. Cytokine Growth Factor Rev 17: 441-450.

38. Francesco Nappo, Katherine Esposito, Michele Cioffi, Giovanni Giugliano, Anna Maria Molinari, et al. (2002) Postprandial endothelial activation in healthy subjects and in type 2 diabetic patients: Role of fat and carbohydrate meals. Am Coll Cardiol 39: 1145-1150.

39. Maric C, Hall JE (2011) Obesity, metabolic syndrome and diabetic nephropathy Contrib Nephrol 170: 28-35. 